v. $13, n .4$

Vitória-ES, Jul.-Aug. 2016

p. $49-71 \quad$ ISSN 1808-2386

DOI: http://dx.doi.org/10.15728/bbr.2016.13.4.3

\title{
Consumer Trust in and Emotional Response to Advertisements on Social Media and their Influence on Brand Evaluation
}

\author{
Ivanete Schneider Hahn ${ }^{\prime}$ \\ Alto Vale do Rio do Peixe University - UNIARP \\ Flavia Luciane Scherer $^{\Omega}$ \\ Federal University of Santa Maria - UFSM \\ Kenny Basso ${ }^{\#}$ \\ Meridional College - IMED \\ Marindia Brachak dos Santos ${ }^{ \pm}$ \\ Federal University of Santa Maria - UFSM
}

\begin{abstract}
Social media is becoming an important part of an organization's media strategy. This study examines the effects of trust and consumer emotional response to advertisements on brand evaluation in an online social media context. The study used a survey method, and the studied population consisted of 927 Brazilian social media users (Facebook subscribers). The results showed the following: (1) the emotional response to advertising on social media had a positive influence on brand evaluation; and (2) consumer trust had a positive influence on brand evaluation and emotional response to advertisements on social media. It is possible to conclude that consumer trust is the key variable to a positive emotional response to advertisements on social media and to a positive brand evaluation. Finally, this study demonstrates that companies must measure the emotional response to advertising in their social media activities as a way of enhancing brand evaluation.
\end{abstract}

Keywords: Social media. Marketing mix. Branding.

Received on 03/10/2015; Reviewed on 05/12/2015; Accepted on 06/29/2015; Divulgued on 07/04/2016.

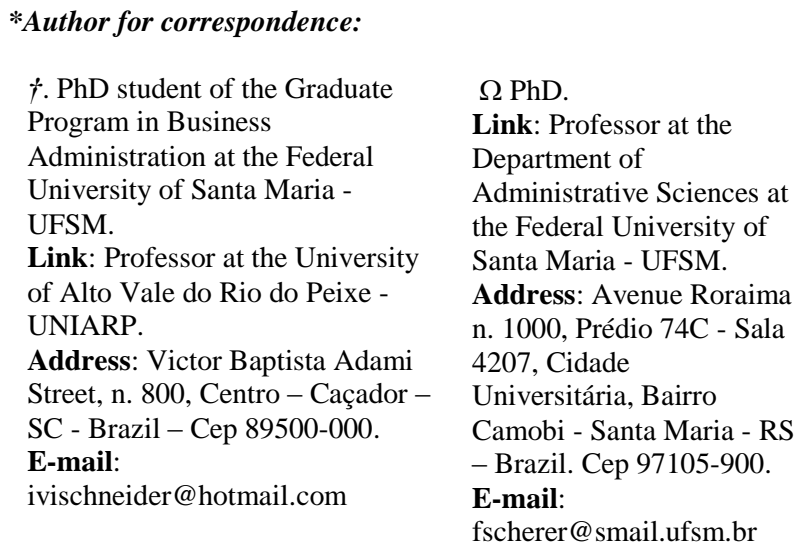

$\begin{array}{ll}\text { ¥ PhD. } & \pm \text { Master. } \\ \text { Link: Professor at the } & \text { Link: PhD student in } \\ \text { IMED Business School. } & \text { Business Administration at } \\ \text { Address: Senador Pinheiro } & \text { the Federal University of } \\ \text { Street, 304, Passo Fundo - } & \text { Santa Maria (UFSM). } \\ \text { RS - Brazil. Cep. 99070- } & \text { Address: Avenue Roraima, } \\ \text { 220. } & \text { n. 1000, Prédio 74C, Sala } \\ \text { E-mail: } & \text { 4207, Cidade Universitária, } \\ \text { bassokenny@ gmail.com } & \text { Bairro Camobi - Santa Maria } \\ & \text { - RS - Brazil. Cep. 97105- } \\ & \text { 900. } \\ & \text { E-mail: } \\ & \text { marindiabrachak@ gmail.com }\end{array}$

Note from the Editor: This paper was accepted by Bruno Felix. 


\section{INTRODUCTION}

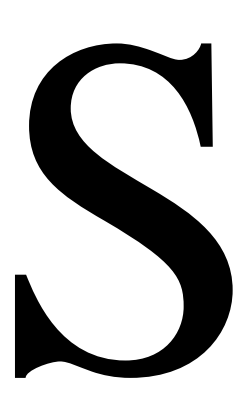

ocial media, with its growing applications and popularity, is a significant strategy for companies to increase consumer engagement, brand awareness and connectivity. In the competitive environment, interaction resources are more vital than ever for brands because consumers make contact with brands and other consumers in social networks and these interactions enable brands to deepen their relationships with consumers (ENGINKAYA; YILMAZ, 2014).

Companies typically embrace social media because of its potential for engagement and collaboration with consumers. Through social media, marketers can gain rich, unmediated consumer insights faster than ever before and can promote loyalty through networking (HUDSON et al., 2015). Additionally, social media has many advantages over traditional channels, such as low cost, customization and ease of creating focused messages (ENGINKAYA; YILMAZ, 2014). Therefore, social media is becoming an increasingly important part of an organization's media strategy (PETERS et al., 2013). This is true for large multinational firms as well as small and medium-sized companies.

Mangold and Faulds (2009) report that social media has become a tool to influence consumer behavior in the areas of awareness, information acquisition, opinions, attitudes, purchasing behavior and post-purchase communication and evaluation. They state that social media has a vital role in promotion because companies can interact with consumers through online platforms (e.g., Facebook, Twitter, MySpace and others).

However, with the growth of online social networks, companies have lost some control over their brands, since information in the online environment is multidirectional, interconnected, and difficult to predict (HENNING-THURAU et al., 2004). Companies ultimately interact with consumers through a "conversation" about the brand (DEIGHTON; KORNFELD, 2009). Judgments about the characteristics or attributes of a person, based on information obtained from digital media, can be accurate (BROWN; VAUGHN, 2011), and online platforms and social networks directly influence the consumer-brand relationship (ENGINKAYA; YILMAZ, 2014). Marketing brands through social media is becoming precise, personal, interesting, interactive and social (JOTHI et al., 2011).

Aware of the power of social media, companies are investing in generating engagement by posting content in the form of advertisements. Notably, companies often use emotional appeals in their advertisements as a way to create affective ties with consumers (KELLY et al., 2010). Therefore, a practical issue is the consumer response to this type of social media 
communication, and it is important to measure consumer reaction to these advertisements to determine if they are able to effectively improve brand evaluation.

The management of brands and the relationships with users of social networks and virtual brand communities (on Facebook in particular) has resulted in an increased interest from the academic community. However, there are few studies regarding the effects of advertising on brand evaluation in the social media environment. Thus, understanding how the emotional reactions of consumers to online advertisements influence brand evaluation is important in understanding how to manage a brand in the online and social media environment. Moreover, this link between the emotional reaction to advertisements in social media and brand evaluation could reveal other factors that may influence the formation of brand awareness.

It is known that a social media user's relationship with a brand may be influenced by other contacts that the consumer has had with the brand. Specifically, the consumer may have a previous trust in the brand. Some studies (DELGADO-BALLESTER; MUNUERAALEMAN, 2005; CHAUDHURI; HOLLBROK, 2001; YACOUB, 2013) have found that trust has a positive influence in brand evaluations. Additionally, trust may also influence the way in which the consumer reacts to the advertisements and the emotional response triggered by the advertisement (SCHOEFER; DIAMANTOPOULOS, 2009). Trust is an important variable in models used to analyze response to advertisements and brand evaluation.

This study examines the effects of trust and consumer emotional response to advertisements on brand evaluation in an online social media context.

This article has five parts. First, we contextualize the general aspects of the research. Then, based on the available literature and the general objective of this study, the theoretical framework and its hypotheses were developed. The third part presents the methodological procedures of the study, which consisted of a cross-sectional survey using structural equation modeling to analyze the data. Then, the results are described and discussed including limitations and suggestions for future studies.

\section{CONSUMER TRUST IN THE ONLINE ENVIRONMENT}

Studies of consumer trust have been gaining in importance for both academia and companies to better understand the relationships between organizations, their members and consumers. Since the 2000s, there has been a significant increase in studies evaluating the impact of trust in business-to-consumer relationships (e.g., JOHNSON; GRAYSON, 2000; 
SIRDESHMUKH; SINGH, 2000; SIRDESHMUKH et al., 2002). More recently, studies on trust in internet exchanges have increased (e.g., URBAN et al., 2009; BELDAD et al., 2010; HABIBI et al., 2014; SCHMIDT; IYERA, 2015).

Rousseau et al. (1998) defined trust as a psychological state comprising the intention to accept vulnerability based on the positive expectations of the intentions or behaviors of another. Garbarino and Johnson (1999) found that trust is antecedent to the perception of value in relationships, given that the construct influences purchase intent and loyalty. In the same sense, trust is very important in the process of building and maintaining relationships (OAKES, 1990; MORGAN; HUNT, 1994). Macintosh (2009) reports that, in services, trust can be more important than in other contexts of marketing because the customer is essentially purchasing a promise. In the online environment, trust is important during the shopping process (POWERS et al., 2012) and is a main antecedent of patronage (PENTINA et al., 2013; SEE-TO; HO, 2014).

Vulnerability and risk are present in the online environment. In this environment, online trust is increasingly important as a subject of study and its influence on the strategies of internet marketing has been gaining prominence (URBAN et al., 2009). Bart et al. (2005) states that online trust includes consumer perceptions of how the page will match their expectations.

The dimensions of trust are intensely debated in the current literature, and trust is becoming a multidimensional construct with cognitive, affective and behavioral dimensions. Regarding affective trust, there is no consensus among authors about its relationship with cognition; however, there is evidence that cognitive and affective systems differ (TERRES; SANTOS, 2013). The behavioral dimension refers to the willingness to act for the transformation of trust in a coherent behavior (CASTALDO, 2003).

In a review of studies of online trust, Urban et al. (2009) concludes that online trust exceeds privacy and security and is closely related to website design, and its formation is a continuous and heterogeneous process among individuals and products. The authors conclude that a website affects trust, which subsequently modifies consumer purchasing, leading to sales and profit. Customers are learning from their experiences of buying and using the product. These experiences build trust and possibly generate word-of-mouth communication in social media. The authors explain that trust has been found to influence consumer behavior, such as in decisions to purchase or hire online or participate in an online community. 
Corritorea et al. (2003) considers trust to be the key element to success in the online environment.

Some researchers have found a link between trust in a brand and brand evaluation (e.g., DELGADO-BALLESTER; MUNUERA-ALEMAN, 2005; CHAUDHURI; HOLLBROK, 2001; YACOUB, 2013). Specifically, Delgado-Ballester and Munuera-Aleman (2005) found that brand trust influences the brand evaluation (equity in that study) through an increase in brand loyalty. Chaudhuri and Hollbrok (2001) also found a positive influence of brand trust on marketing share and relative price of the brand, both mediated by loyalty (purchase and attitudes through the brand). Yacoub (2013) showed the importance of the introduction of a relationship approach based on trust in brand extension. He found that if a brand has built a sufficient level of trust with consumers and essentially good credibility, it will improve the evaluation of the brand.

Notably, there is evidence that brand trust is also linked to emotional response to advertisements. Specifically, Chaudhuri and Hollbrok (2001) found that brand trust and brand affect have a positive correlation. Drossos et al. (2007) showed that trust strongly influences a consumer's attitude toward the advertiser, and is an important predictor of the consumer's behavioral intention toward the advertisement.

Brand trust may have a positive impact on the reaction of the consumer to the brand advertisements on online social media, and, in the same way, brand trust may increase the consumer's evaluation of the brand. These statements give support to the following hypotheses:

H1 - Consumer trust has a positive influence on the emotional response to advertisements.

H2 - Consumer trust has a positive influence on brand evaluation.

\section{EMOTIONAL RESPONSE TO ADVERTISEMENTS IN SOCIAL MEDIA AND BRAND EVALUATION}

With the increase of the number of media, the task of understanding and targeting consumers has become more complex. Advertising is the most visible component of integrated marketing communications. In addition to advertising, Grewal and Levy (2012) report that web sites, corporate blogs, social media and online games are potential means of communication between companies and customers, for direct purchase, consumer service (complaints and suggestions) or relationships. 
Companies are using social media for digital advertising, mining innovative ideas and creating engaged brand communities (ENGINKAYA; YILMAZ, 2014). Thus, social media is a relationship tool, a promotion tool and a sales channel (SERRA et al., 2013). Content previously only generated by marketing professionals can now be generated by users and has the potential to shape the perception of consumers. A thorough understanding of this is important for marketers that aim to promote their brands socially (SMITH et al., 2012).

Also related to marketing strategies (EL-ANSARY, 2006), the brand is a dynamic and strategic dimension in business management, to the point of becoming a new competence in marketing (PRADO, 2008). When the variables of brand are managed, i.e., identity and brand image, a positive brand evaluation is obtained as a result. Louro (2000) suggests that brand evaluation is a liability to the extent that negative associations (if the perceived quality of the product is lower than expected) will penalize the marketing efforts of the company. In contrast, the emotional response of the media user has been suggested to influence attitudes towards advertisements and the brand (BATRA; RAY, 1986; DERBAIX, 1995). Additionally, Dobele et al. (2007) reports that emotional connection plays a critical role in influencing forwarding behavior, such as a positive brand evaluation on social media.

It is necessary for brands to build a connection with users and to nurture a sense of belonging in customers. With its diverse tools, social media satisfies consumer desire for engagement and they may wish to be associated with a brand. Brands are strengthened through creating participation, allowing external audiences to identify with them and become involved (YAN, 2011). Additionally, previous research suggests that consumers respond much more positively to content shared through social media than to paid online advertising (NEFF, 2012).

The emotional response to social media interactions strengthens the relationship with the brand (MANGOLD; FAULDS, 2009; SASHI, 2012). However, it is necessary to understand that emotions are ubiquitous throughout marketing. In other words, emotions are a person's positive (i.e., pleased or relaxed) and negative (i.e., nervous or annoyed) feelings (LEE et al., 2009). In addition, researchers have found that high levels of emotional content in communications will encourage strong brand relationships (HEATH et al., 2006; PAWLE; COOPER, 2006; HUDSON et al., 2015). From this information in the current literature, the final hypotheses is proposed regarding the use of social media in advertising strategies and brand evaluation. 
H3 - Consumer emotional response to advertisements on social media has a positive influence on brand evaluations.

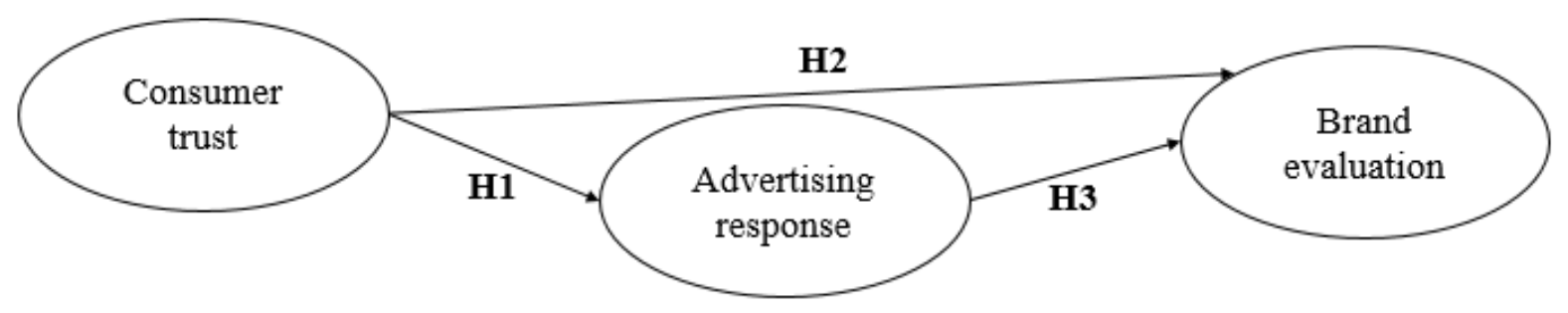

Figure 1 - Theoretical model

Source: Developed by the authors.

\section{DATA COLLECTION AND METHODOLOGY}

The methodological procedures used in this study followed the steps proposed by Hair Jr. et al. (2005) for the cross-sectional survey method.

\subsection{MEASURES}

In the data collection instrument, the following scales were used from Brazilian studies: consumer trust from Terres and Santos (2013); emotional response to advertising from Mello et al. (2006); and brand evaluation from Pereira et al. (2006). The scales and the univariate analysis for each item are listed in Appendix A.

The data collection instrument was divided into two parts. The first part contained the characteristics of the respondents (gender, age, state and academic degree, digital fluency, frequency of computer use and frequency of access to Facebook). The second part contained scales regarding the following: (1) consumer trust - presenting 12 observed variables divided into three unobservable variables (affective, behavioral and cognitive); (2) emotional response to advertising - with 15 observable variables contained in three unobservable variables (attractiveness, significance and utility); and (3) brand evaluation - presenting 20 observed variables divided into five unobservable variables (brand image, current and future intentions, company image, tradition of the brand and beliefs regarding the role of the brand in society).

The measurement scale was a Likert scale, where respondents responded in degrees of agreement from 1 (strongly disagree) to 5 (strongly agree). Online data collection occurred from May 2013 and July 2013.

\subsection{RESEARCH SAMPLE}

The studied population was Brazilian social media users, subscribers to Facebook, which had approximately 76 million users at the end of July 2013 (REUTERS BRASIL, 2013). We obtained 1,037 questionnaires, according to the recommendations of Kline (2011) 
on the minimum sample size for Structural Equation Modeling (SEM). With the aid of the researchers' networks, invitations were distributed through digital media (email, Facebook, closed groups) containing a link to complete the online survey.

This sample cannot be considered probabilistic, given that the probability of inclusion of each member of the population in the sample is not known or equivalent (MALHOTRA, 2001). However, because of the amplitude (there are individuals from the majority of the Brazilian states) and the number of individuals, we consider that the sample positively influences the external validity of the findings.

This study used the Coca-Cola brand to evaluate the hypothesis because it was necessary to use a real brand to study the effects of brand trust and emotional response to advertising on brand evaluation. Therefore, some aspects were important to the brand definition. In the context of brands, the Coca-Cola Company is highlighted as an iconic brand in history, present in more than 200 countries. With over 400 brands of soft drinks, this company owns four of the five most consumed brands globally (Coca-Cola, Coca-Cola Light, Fanta and Sprite). Additionally, the brand has been recognized for 13 consecutive years as the most valuable brand in the world (INTERBRAND, 2012). In the latest ranking by Interbrand (2013), Coca-Cola appears as the third most valuable brand in the world, with an estimated value of over 79 billion dollars. Coca-Cola is the most followed brand on Facebook with over 73 million followers around the world (SOCIALBAKERS, 2013). It was cogent to study Coca-Cola due to its deep social significance throughout history and because Facebook users are familiar with the brand.

\subsection{DATA ANALYSIS}

The collected data were analyzed using the software SPSS Statistics 21 and AMOS 21 using the multivariate technique of structural equation modeling with the following steps: (1) preparation of the data matrix (identification of outliers, missing values, the distribution of data, multicollinearity and homoscedasticity and selection of the estimation method); (2) descriptive analysis of the sample (to present the respondents profiles); (3) multivariate analysis using Exploratory Factor Analysis (EFA) to determine the underlying structure of the dataset from the survey; and (4) multivariate analysis by Confirmatory Factor Analysis (CFA) of the structure to verify unidimensionality, reliability, convergent and discriminant validity, and calculating the coefficient of determination for structural equations. 


\subsection{PREPARATION OF THE DATA MATRIX}

First, we tested the statistical assumptions on multivariate applications, noting the complexity of the relationships and the number of variables, which can result in significant biases and distortions (HAIR Jr. et al., 2005). To minimize this, the collected data passed through the following treatments: identification of outliers, missing values, the distribution of data, multicollinearity and homoscedasticity.

Using a simple frequency distribution, no questionnaires with missing data were identified. The univariate outliers were identified by calculating $\mathrm{Z}$ score, where all data showed values less than |3| (HAIR JRr. et al., 2005). The multivariate outliers were identified using the Mahalanobis Distance (level of significance 0.001, as suggested by Hair et al. (2005)); 110 questionnaires presented outliers and were excluded.

Analysis of normality was verified using the Kolmogorov-Smirnov test and no abnormal variables were observed. Multicollinearity was verified by the values of tolerance and the Variance Inflation Factor (VIF). Two variables (V76 and V78) from the brand evaluation presented a higher level of multiple associations and were removed from further analysis.

To measure homoscedasticity, we used Levene's test at a significance level of $1 \%$. Through an ANOVA, we found that no variables were heteroscedastic; therefore, no additional variables were excluded from further analysis.

\subsection{SAMPLE CHARACTERISTICS}

The sample used in this study comprised 927 questionnaires. Respondents were obtained from 22 Brazilian states. The average age of the respondents was 27 years old, with the most common age group between 17 and 29 years old (minimum age recorded was 14 and the maximum 68). The sample consisted of $56.3 \%$ women and $43.7 \%$ men. According to information from Socialbakers (2013), the largest group of Facebook users in Brazil are women (54\% of profiles) and the age range of the majority of users is between 18 and 34 years old (59\%). Therefore, the average age and gender of the sample are within the characteristics of Facebook users in Brazil.

With regard to marital status, there was a large concentration of single individuals (67.4\% of respondents), and $30.0 \%$ of respondents were married. The respondents had a high level of education ( $43 \%$ were graduates, $52 \%$ were students or undergraduates). In regard to computer use, $98.9 \%$ of the sample uses a computer every day and $49.4 \%$ of the respondents 
confirmed that they accessed Facebook multiple times a day and $40.9 \%$ accessed it at least once a day.

The data recorded by the variables, related to the profile of the respondents, showed a prevalence of women (56.3\%), young people (between 17 and 29 years old), and singles (67.4\%), with a high level of education who were technologically fluent and highly connected to Facebook.

\section{RESULTS}

\subsection{CONSTRUCT INDIVIDUAL VALIDATION}

The validation procedures of the constructs contained in the measurement model sought to verify unidimensionality, reliability, and convergent and discriminant validity. The dimensionality of the constructs was verified by Exploratory Factor Analysis (EFA) with extraction of the main components and an Oblimin rotation with indicators of the three constructs (consumer trust, emotional response to advertising and brand evaluation) (Table 1).

Table 1 - Exploratory Factor Analysis Solution

\begin{tabular}{|c|c|c|c|c|}
\hline & $\begin{array}{l}\text { Number } \\
\text { of factors }\end{array}$ & $\begin{array}{c}\text { Number of } \\
\text { observable variables }\end{array}$ & $\begin{array}{c}\text { Cumulative } \\
\text { variance }(\%)\end{array}$ & $\begin{array}{c}\text { KMO* } \\
\text { solution }\end{array}$ \\
\hline Consumer trust & 2 & 9 & 63.16 & 0.853 \\
\hline Emotional response to advertising & 3 & 11 & 66.57 & 0.888 \\
\hline Brand Evaluation & 4 & 18 & 70.47 & 0.911 \\
\hline
\end{tabular}

KMO: Kaiser-Meyer-Olkin measure

Source: Authors' calculations based on survey data.

After the EFA, consumer trust presented nine observed variables divided into two first order unobservable variables (affective and cognitive). As previously mentioned, the dimensions of trust are intensely debated in the literature and there is no consensus among researchers. At the same time, the behavioral dimension was less adherent to the model, since the study was scaled to consumer trust.

Emotional response to advertising, with 11 observable variables, was contained in three first order unobservable variables (attractiveness, significance and utility). In this model, some variables were more adherent to other constructs (different from the original) and were relocated after a careful analysis.

The brand evaluation scale presented the best fit, considering that only two variables were excluded due to a higher level of multiple associations (V76 and V78). Therefore, after the EFA, the construct presented 18 observed variables divided into four first order 
unobservable variables (brand image, current and future intentions, company image and beliefs regarding the role of the brand in society).

The evaluation of the reliability of the scales was performed by calculating the composite reliability and the average variance extracted for each construct measured (FORNELL; LARCKER, 1981). The average variance extracted and reliability for each construct is displayed in Table 2.

Table 2 - Variance Extracted and Reliability of the Constructs

\begin{tabular}{lcc}
\hline \multicolumn{1}{c}{ Construct } & $\begin{array}{c}\text { Analysis of variance } \\
\text { extracted }\end{array}$ & $\begin{array}{c}\text { Reliability of the } \\
\text { construct }\end{array}$ \\
\hline Consumer trust & 0.56 & 0.92 \\
\hline Emotional response to advertising & 0.63 & 0.95 \\
\hline Brand Evaluation & 0.67 & 0.97 \\
\hline
\end{tabular}

Source: Authors' calculations based on survey data

Acceptable reliability must comply to values equal to or greater than 0.7 for the reliability of the construct and equal to or greater than 0.5 for the variance extracted (HAIR JR. et al., 2005). All constructs presented the recommended extracted variance and reliability.

The convergent validity was assessed by examining the significance of the estimated parameters from their T-values, and all values refer to t-values greater than 1.96 (GARVER; MENTZER, 1999). The discriminant validity, according to Fornell and Larcker (1981), refers to the comparison between the variance extracted from each construct with the shared variance with the other constructs (squared correlation coefficient). Notably, the values of the first must be greater than the values found in the second. Table 3 presents the values of the bivariate correlation and shared variance.

Table 3 - Shared Variance Between the Constructs

\begin{tabular}{lcc}
\hline \multicolumn{1}{c}{ Construct } & $\begin{array}{c}\text { Coefficient of } \\
\text { correlation }\end{array}$ & $\begin{array}{c}\text { Square of the correlation } \\
\text { coefficient }\end{array}$ \\
\hline Consumer trust --- brand evaluation & 0.459 & 0.210 \\
Emotional response to advertisement ---consumer trust & 0.400 & 0.160 \\
Emotional response to advertisement --- brand evaluation & 0.592 & 0.350 \\
\hline
\end{tabular}

Source: Authors' calculations based on survey data.

In the analysis of discriminant validity, the emotional response to the advertisement and brand evaluation pair presented the highest shared variance (square of the correlation coefficient). However, as evidence by the discriminat validity, the shared variance is lower than the coefficient of correlation between the two constructs. Thus, all constructs presented evidence of discriminant validity. 
The model tested had 38 variables and 100 estimated parameters (Figure 2 in Appendix B). The model was evaluated using the technique of structural equation modeling, analyzing the measures of adjustment of the model (Table 4), the level of significance and the magnitude of the estimated regression coefficients for the relationships proposed by the hypotheses of the study.

Table 4 - Model Fit

\begin{tabular}{cc}
\hline Measure & Adjustment \\
\hline Chi-Square (QQ) & 1952.32 \\
Degrees of freedom (DF) & 642 \\
QQ / GL (CMIN / DF) & 3.041 \\
Probability & 0.000 \\
GFI & 0.893 \\
AGFI & 0.876 \\
IFI & 0.933 \\
RMSEA & 0.046 \\
TLI & 0.927 \\
CFI & 0.933 \\
\hline
\end{tabular}

Source: Authors' calculations based on survey data.

The results presented in Table 5 show that the model has an acceptable adjustment. The chi-square did not show significance and its relationship with the degrees of freedom was an acceptable value (3.04). The Root Mean Square Error of Approximation (RMSEA) was within the patterns of adjustment proposed by Ullman (2006). The Goodness of Fit Index (GFI) and the Adjusted Goodness of Fit Index (AGFI) measures demonstrated acceptable adjustment values (greater than 0.8). The Tucker-Lewis Index (TLI), Incremental Fit Index (IFI) and Comparative Fit Index (CFI) indicators showed large adjustment values (greater than 0.9).

\subsection{TEST OF HYPOTHESES}

The analysis of the significance and standardized factor loads and variance allowed the verification of the hypotheses of the study (Table 5). 
Table 5 - Estimated Parameters of the Model and Hypotheses Status

\begin{tabular}{|c|c|c|c|c|}
\hline & $\begin{array}{c}\text { Standardized } \\
\text { beta }\end{array}$ & T-value & Sig. & $\begin{array}{c}\text { Hypotheses } \\
\text { status }\end{array}$ \\
\hline $\begin{array}{l}\text { H1 - Consumer trust has a positive influence on the } \\
\text { emotional response to advertisement. }\end{array}$ & 0.55 & 8.89 & $* * *$ & Supported \\
\hline $\begin{array}{l}\mathrm{H} 2 \text { - Consumer trust has a positive influence on brand } \\
\text { evaluation. }\end{array}$ & 0.47 & 8.34 & $* * *$ & Supported \\
\hline $\begin{array}{l}\text { H3 - Consumer emotional response to advertisements on } \\
\text { social media has a positive influence on brand evaluations. }\end{array}$ & 0.46 & 8.29 & $* * *$ & Supported \\
\hline
\end{tabular}

The H1 hypothesis (consumer trust has a positive influence on the emotional response to advertisements) was supported. The results showed that consumer trust has a positive effect on emotional response to advertisements. When trust increases 1 point, the emotional response to advertising increases 0.55 points. The result of the $\mathrm{H} 1$ hypothesis allows us to evaluate the influence that consumer trust has on the emotional response to advertising in social media. We concluded that consumer trust is an immediate antecedent of emotional response to the advertisements on social media, and the higher the consumer trust, the more positive the reaction concerning the insertion of advertisements in social media.

The $\mathrm{H} 2$ hypothesis (consumer trust has a positive influence on brand evaluation) was also supported. The results demonstrated that when consumer trust increases 1 point, brand evaluation increases by 0.47 points. Therefore, there is a positive effect of consumer trust on brand evaluation.

The final hypothesis, H3 (consumer emotional response to advertisements on social media has a positive influence on brand evaluations), was also supported. The results showed that when the emotional response to advertising increases by 1 point, brand valuation increases by 0.46 points. This result allows us to evaluate the influence that the emotional response to advertisements on social media has on the evaluation of the Coca-Cola brand. Therefore, the better the emotional response to the advertisement, the better the brand evaluation will be.

The results of the evaluation and adjustment of the structural model can be summarized as follows: (1) the emotional response to advertisements on social media had a positive influence on the evaluation of the Coca-Cola brand; and (2) consumer trust had a positive influence on brand evaluation and emotional response to advertising in social media. 


\section{DISCUSSION AND THEORETICAL IMPLICATIONS}

In the age of social media, great importance is placed on gaining customer engagement with the community and the brand. Therefore, companies are investing in different forms of advertising and in methods to measure these strategies.

Our findings provide insights on how the emotional response to advertisements in a social media context and consumer trust influence brand evaluation. Specifically, we found that the trust that consumers have in the brand positively influences both the emotional response to advertisements and the brand evaluation. Notably, an increase in a consumer's previous trust in the brand implies an increased emotional response to advertisements distributed via online social media. This relationship between brand trust and emotional response to advertising demonstrates that the perception that consumers have about online communications is influenced by how they perceive the brand (whether they trust the brand).

Similarly, brand trust is an important influence on brand evaluation. If there is an increase in the trust that the consumer has in the brand, this will positively affect the beliefs and images that the consumer has about the brand. In this sense, the more the trust, the better the perception about the image of the brand. This finding is in agreement with previous studies that found that brand trust has a positive influence on behavioral and attitudinal dimensions of loyalty (e.g., CHAUDHURI; HOLBROOK, 2001; LAROCHE et al., 2012).

We also found that the emotional response to the advertisements on social media will positively influence brand evaluations. If the consumer has a positive emotional reaction to an online advertisement of the brand, the more positively the consumer will perceive the brand. This link between emotional response to the advertisements and brand evaluation contributes to a better understanding the role of the online media and how this media influences performance variables, such as brand evaluation.

Therefore, our results empirically support why consumer trust matters in social media contexts. First, consumers with higher levels of trust evaluated the brand more positively and have a positive emotional response to advertising on Facebook. Likewise, consumers that had a positive emotional response to advertising on Facebook evaluated the brand more positively. Thus, we demonstrated that the social media user's relationship with the brand may be prior to the online relationship, and that the emotional response systematically corresponds to different trust perceptions (SCHOEFER; DIAMANTOPOULOS, 2009). 
In addition, this research offers practical implications for brand managers, focusing the practitioners' attention to the types of advertising they use in social media. The practice of the companies to use emotional appeals in their advertisements as a way to create affective ties with consumers (KELLY et al., 2010) has proven to be effective for positive brand evaluations. These results also confirmed that high levels of emotional content in the online environment will encourage strong brand relationships (HEATH et al., 2006; PAWLE; COOPER, 2006; HUDSON et al., 2015).

This study demonstrates that companies must measure the emotional response to advertising in their social media activities as a way of enhancing brand evaluation. Managers should assess community success in social media by measures such as trust, not just the number of active users, posts, or visitors (HABIBI et al., 2014).

Finally, our research highlights the importance of building trust in the online environment, specifically on social media. Based on these results, the recommendation to the management is that trust plays a key role in attracting and retaining costumers (CORRITOREA et al., 2003; SRINIVASAN, 2004; SEE-TO; HO, 2014). Therefore, companies should employ and manage rich content in social media because marketing brands through social media is precise, personal, interesting, interactive and social (JOTHI et al., 2011).

\subsection{LIMITATIONS AND FUTURE RESEARCH}

The results showed that it is possible to correlate the constructs of consumer trust and emotional response to advertising and brand evaluation, which are very common in marketing even though they have been primarily studied in an isolated form. However, more replications are necessary because we used an online survey method.

This study is limited in scope because only one social media tool (Facebook) and one brand (Coca-Cola) were used. Therefore, there is a need for the reapplication of this method to other brands that are less well known, such as Havaianas or local brands. Additionally, another social media tool should be analyzed. Third, future studies using the cross-sectional method used should observe changes in situational and superficial traits that were not assessed here.

Even with its limitations, this study adds a new perspective to the measurement of brand evaluation for companies that use social media as a marketing strategy. 


\section{CONTRIBUTIONS OF AUTHORS}

Ivanete Schneider Hahn: primarily responsible for the research, and the results were used in the master dissertation.

Flavia Luciane Scherer: Advisor of the research and dissertation.

Kenny Basso: guiding the data analysis and the preparation of the article.

Marindia B. dos Santos: directly assisted in data collection.

\section{REFERENCES}

BART, I. Y. et al. Are the drivers and role of online trust the same for all web sites and consumers? A large-scale exploratory empirical study. Journal of Marketing, v. 69, n. 4, p. 133-152, 2005.

BATRA, R.; RAY, M. I. Affective responses mediating acceptance of advertising. Journal of Consumer Research, v. 13, n. 2, p. 234-250, 1986.

BELDAD, A.; JONG, M.; STEEHOUDER, M. How shall I trust the faceless and the intangible? A literature review on the antecedents of online trust. Computers in Human Behavior, v. 26, p. 57-869, 2010.

BROWN, V. R.; VAUGHN, D. The writing on the (Facebook) wall: the use of social. networking sites in hiring decisions. Journal of Business and Psychology, v. 26, p. 219-225, 2011.

CASTALDO, S. Trust variety: conceptual nature, dimensions and typologies. In: IMP CONFERENCE, 2003, Lugano (Switzerland). Proceedings... Lugano: IMP, 2003.

CHAUDHURI, A.; HOLBROOK, M. B. The chain of effects from brand trust and brand affect to brand performance: the role of brand loyalty. Journal of marketing, v. 65, n. 2, p. 81-93, 2001.

CORRITOREA, C. L.; KRACHERA, B.; WIEDENBECKQUE, S. On-line trust: concepts, evolving themes, a model. International Journal of Human-Computer Studies, v. 58, p. 737-758, 2003.

DEIGHTON, J.; KORNFELD, L. Interactivity's unanticipated consequences for marketers and marketing. Journal of Interactive Marketing, v. 23, p. 4-10, 2009.

DELGADO-BALLESTER, E.; LUIS MUNUERA-ALEMÁN, J. Does brand trust matter to brand equity? Journal of Product \& Brand Management, v. 14, n. 3, p. 187-196, 2005.

DERBAIX, C. M. The impact of affective reactions on attitudes toward the advertisement and the brand: a step toward ecological validity. Journal of Marketing Research, v. 32, n.4, p.479-479, 1995.

DOBELE, A. et al. Why pass on viral messages? Because they connect emotionally. Business Horizons, v. 50, n. 4, p. 291-304, 2007. 
DROSSOS, D. et al. Determinants of effective SMS advertising: an experimental study. Journal of Interactive Advertising, v. 7, n. 2, p. 16-27, 2007.

EL-ANSARY, A. I. Marketing strategy: taxonomy and frameworks. European Business Review, v. 18, n. 4, p. 266-293, 2006.

ENGINKAYA, E.; YILMAZ, H. What drives consumers to interact with brands through social media? A motivation scale development study. Procedia - Social and Behavioral Sciences, n. 148, p. 219-226, 2014.

MELLO, S. C. B. et al. Acessando a reação emocional à propaganda por meio da escala de Wells. Faces Revista de Administração, v. 5, n. 1, p. 26-40, 2006.

FORNELL, C.; LARCKER, D.F. Evaluating structural equation models with unobservable variables and measurement error. Journal of Marketing, v. 18, n. 1, p. 39-50, fev. 1981.

GARBARINO, E.; JOHNSON, M. S. The different roles of satisfaction, trust, and commitment in customer relationships. Journal of Marketing, v. 63, n. 2, p. 70-87, abr. 1999.

GARVER, M. S.; MENTZER, J. T. Logistics research methods: employing structural equation modeling to test for construct validity. Journal of Business Logistics, v. 20, n. 1, p. 33-57, 1999.

GREWAL, D.; LEVY, M. Marketing: integrando a ética em estratégias de publicidade e precificação. 2. ed. Porto Alegre: AMGH, 2012.

HABIBI, M. R.; LAROCHE, M.; RICHARD, M. The roles of brand community and community engagement in building brand trust on social media. Computers in Human Behavior, v. 37, n. 152-161, 2014.

HEATH, R.; BRANDT, D.; NAIRN, A. Brand relationships: strengthened by emotion, weakened by attention. Journal of Advertising Research, v. 46, n. 4, p. 410-419, 2006.

HAIR JR., J. F. et al. Análise multivariada de dados. 5. ed. Porto Alegre: Bookman, 2005.

HENNING-THURAU, T. et al. Electronic word-of-mouth via consumer-opinion platforms: what motivates consumers to articulate themselves on the internet? Journal of Interactive Marketing, v. 18, n. 1, p. 38-52, 2004.

HUDSON, S. et al. The effects of social media on emotions, brand relationship quality, and word of mouth: An empirical study of music festival attendees. Tourism Management, v. 47, p. 68-76, 2015.

INTERBRAND. BEST GLOBAL BRANDS 2012. 2012. Disponível em: <http://www.interbrand.com/pt/best-global-brands/2012/Best-Global-Brands-2012.aspx>. Acesso em: jun. 2013.

2013. Disponível em: <http://www.interbrand.com/en/best-global-brands/2013/CocaCola>. Acesso em: jun. 2013. 
JOHNSON, D. S.; GRAYSON, K. Sources and dimensions of trust in service relationships. Handbook of Service Relationship, p. 357-370, 2000.

JOTHI, P. S. J.; NEELAMALAR M.; PRASAD, R. S. Analysis of social networking sites: a study on effective communication strategy in developing brand communication. Journal of Media and Communication Studies, v. 3, n. 7, p. 234-242, 2011.

KELLY, L.; KERR, G.; DRENNAN, J. Avoidance of advertising in social networking sites: the teenage perspective. Journal of Interactive Advertising, v. 10, n. 2, p. 16-27, 2010.

KLINE, R.B. Principles and practice of structural equation modeling. 3. ed. New York, Guilford, 2011.

PEREIRA, R. C. F.; ALMEIDA, S. O.; LAUX, F. N. Marketing de gerações: construção e teste de escala para avaliação da marca de refrigerantes Coca-Cola por jovens na fase de transição entre as gerações X e Y. REAd - Revista Eletrônica de Administração, v. 12, n. 4, 2006.

LAROCHE, M. et al. The effects of social media based brand communities on brand community markers, value creation practices, brand trust and brand loyalty. Computers in Human Behavior, v. 28, n. 5, p. 1755-1767, 2012.

LEE, Y.; BACK, K.; KIM, J. Family restaurant brand personality and its impact on customer's emotion, satisfaction, and brand loyalty. Journal of Hospitality \& Tourism Research, v. 33, n.3, p. 305-328, 2009.

LOURO, M. J. S. Modelos de avaliação de marca. Revista de Administração de Empresas, v. 40, n. 2, p. 26-37, abr./jun. 2000.

MACINTOSH, G. Examining the antecedents of trust and rapport in services: Discovering new interrelationships. Journal of Retailing and Consumer Services, v. 16, p. 298-305, 2009.

MALHOTRA, N. K. Pesquisa de marketing: uma orientação aplicada. 3. ed. Porto Alegre/RS: Bookman, 2001.

MANGOLD, W. G.; FAULDS, D. Social media: the new hybrid element of the promotion mix. Business Horizons, v. 52, n. 4, p. 357-365, 2009.

MORGAN, R. M.; HUNT, S. D. The commitment-trust theory of relationship marketing. Journal of Marketing, v. 58, p. 20-38, 1994.

NEFF, J. GE study proves consumers respond more to shared content than to paid placements. 2012. Disponível em: <http://adage.com/article/digital/ge-study-provesconsumers-respond-shared-content/232324/>. Acesso em: maio 2015.

OAKES, G. The sales process and the paradoxes of trust. Journal of Business Ethics, v. 9, n. 8, p. 671-679, 1990.

PAWLE, J.; COOPER, P. Measuring emotion e lovemarks, the future beyond brands. Journal of Advertising Research, v. 46, n. 1, p. 38-48, 2006. 
PENTINA, I.; ZHANG, L.; BASMANOVA, O. Antecedents and consequences of trust in a social media brand: a cross-cultural study of Twitter. Computers in Human Behavior, v. 29, n. 4, p. 1546-1555, 2013.

PETERS, K. et al. Social media metrics: a framework and guidelines for managing social media. Journal of Interactive Marketing, v. 27, p. 281-298, 2013.

PHAM, M. T.; GEUENS, M.; PELSMACKER, P. The influence of ad-evoked feelings on brand evaluations: empirical generalizations from consumer responses to more than $1000 \mathrm{TV}$ commercials. International Journal of Research in Marketing, v. 30, n. 4, p. 383-394, 2013.

POWERS, T. et al. Digital and social media in the purchase decision process: a special report from the Advertising Research Foundation. Journal of Advertising Research, v. 52, n. 4, p. 479-489, 2012.

PRADO, K. P. L. A. A preferência da marca no processo de compra: um estudo exploratório no segmento de baixa renda. 2008. Tese (Doutorado) - Programa de PósGraduação em Administração, Universidade de São Paulo (USP), São Paulo (SP), 2008.

REUTERS BRASIL. América Latina impulsiona resultados do Facebook. Available on: $<$ http://br.reuters.com/article/internetNews/idBRSPE97009R20130801?pageNumber=2 HYPERLINK "http://br.reuters.com/article/internetNews/idBRSPE97009R20130801?pageNumber=2\&virtu alBrandChannel=0"\& HYPERLINK

"http://br.reuters.com/article/internetNews/idBRSPE97009R20130801?pageNumber=2\&virtu alBrandChannel=0"virtualBrandChannel=0>. Acesso em: jun. 2013.

ROUSSEAU, F. M. et al. Not so different after all: a cross-discipline view of trust. The Academy of Management Review, v. 23, p. 393-404, 1998.

SASHI, C. M. Customer engagement, buyereseller relationships, and social media. Management Decision, v. 50, n. 2, p. 253-272, 2012.

SCHMIDT, K. N.; IYERA, K. S. Online behaviour of social media participants' and perception of trust, comparing social media brand community groups and associated organized marketing strategies. Procedia - Social and Behavioral Sciences, v. 177, p. 432439, 2015.

SCHOEFER, K.; DIAMANTOPOULOS, A. A typology of consumers' emotional response styles during service recovery encounters. British Journal of Man, v. 20, n. 3, p. 292-308, 2009.

SEE-TO, E. W. K.; HO, K. K. W. Value co-creation and purchase intention in social network sites: The role of electronic Word-of-Mouth and trust: a theoretical analysis. Computers in Human Behavior, v. 31, p. 182-189, 2014.

SERRA, B. et al. Mídias sociais e negócios: um estudo Delphi. Revista Ibero-Americana de Estratégia, São Paulo, v. 12, p. 1, p. 236-253, 2013. 
SIRDESHMUKH, D.; SINGH, J. Agency and trust mechanisms in consumer satisfaction and loyalty judgments. Journal of the Academy of Marketing Science, v. 28, n. 1, p. 150-167, 2000.

SIRDESHMUKH, D.; SINGH, J.; SABOL, B. Consumer trust, value and loyalty in relational exchanges. Journal of Marketing, v. 66, n. 1, p. 15-37, 2002.

SMITH, A. N.; FISCHER, E.; YONGJIAN C. How does brand-related user-generated content differ across YouTube, Facebook, and Twitter? Journal of Interactive Marketing, v. 26, p. 102-113, 2012.

SRINIVASAN, S. Role of trust in e-business success. Information Management \& Computer Security, v. 12, n. 1, p. 66-72, 2004.

SOCIALBAKERS. User age distribution. 2013. Disponível em:

<http://www.socialbakers.com/facebook-statistics/brazil>. Acesso em: jun. 2013.

TERRES, M. S.; SANTOS, C. P. Desenvolvimento de uma escala para mensuração das confianças cognitiva, afetiva e comportamental e seus impactos na lealdade. Revista Brasileira de Marketing, v. 12, n. 1, p. 122-148, 2013.

ULLMAN, J. M. Structural equation modeling: reviewing the basics and moving forward. Journal of Personality Assessment, v. 87, n. 1, p. 35-50, 2006.

URBAN, G. L.; AMYX, C.; LORENZON, A. Online trust: state of the art, new frontiers, and research potential. Journal of Interactive Marketing, v. 23, p. 179-190, 2009.

YACOUB, I. The evaluation of brand extension through a relationship perspective based on trust. International Journal of Advances in Management and Economics, v. 2, n. 2, p. 117, 2013.

YAN, J. Social media in branding: fulfilling a need. Journal of Brand Management, v. 18, p. 688-696, 2011. 


\section{APPENDIX A}

Table 6 - Observable Variables and Analysis of Consumer Trust

\begin{tabular}{|c|c|c|c|c|}
\hline & Observable variable & Name & Mean & $\begin{array}{l}\text { Standard } \\
\text { deviation }\end{array}$ \\
\hline \multirow{4}{*}{ 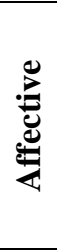 } & I feel that Coca-Cola is interested in me. & V36 & 2.18 & 1.173 \\
\hline & I feel that Coca-Cola demonstrates attention towards me. & V37 & 2.13 & 1.111 \\
\hline & $\begin{array}{l}\text { I feel that if I have a problem with Coca-Cola, they are always ready to } \\
\text { listen. }\end{array}$ & V38 & 2.28 & 1.111 \\
\hline & $\begin{array}{l}\text { I feel that Coca-Cola, despite having their own interests, take into } \\
\text { consideration what is best for me too. }\end{array}$ & V39 & 2.01 & 1.010 \\
\hline \multirow{4}{*}{ 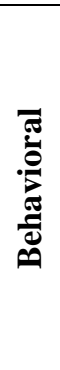 } & $\begin{array}{l}\text { I share information openly with Coca-Cola, because they will not take } \\
\text { advantage of me. }\end{array}$ & V40 & 1.95 & 0.979 \\
\hline & $\begin{array}{l}\text { I do not question the statements of this service provider on their } \\
\text { competence. }\end{array}$ & V41 & 2.75 & 1.099 \\
\hline & $\begin{array}{l}\text { I do not monitor possible changes, for example, economic or changes in } \\
\text { legislation, because I know that Coca-Cola will not take advantage of } \\
\text { these changes. }\end{array}$ & V42 & 2.33 & 1.050 \\
\hline & $\begin{array}{l}\text { (R) I share personal information in a careful manner with Coca-Cola, to } \\
\text { prevent them from taking advantage. }\end{array}$ & V43 & 2.65 & 1.104 \\
\hline \multirow{4}{*}{ 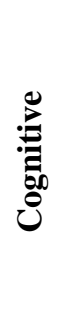 } & $\begin{array}{l}\text { Given the historical relationship with Coca-Cola, I have good reason to } \\
\text { believe in the information provided by them. }\end{array}$ & V44 & 2.66 & 1.025 \\
\hline & $\begin{array}{l}\text { (R) Given the historical relationship with Coca-Cola, I have reason to } \\
\text { doubt the competence of the institution. }\end{array}$ & V45 & 2.69 & 0.991 \\
\hline & $\begin{array}{l}\text { Given my past relationship with Coca-Cola, I have no reason to doubt its } \\
\text { efficiency. }\end{array}$ & V46 & 3.01 & 1.041 \\
\hline & $\begin{array}{l}\text { The Coca-Cola company is constantly worried about keeping their } \\
\text { services working properly. }\end{array}$ & V47 & 3.42 & 0.996 \\
\hline
\end{tabular}

Source: Authors' calculations based on survey data

Note: $(\mathrm{R})$ reverse coding

Table 7 - Observable Variables and Analysis of Emotional Response to Advertisements

\begin{tabular}{lccc}
\multicolumn{1}{c}{ Observable variable } & Name & Mean & $\begin{array}{c}\text { Standard } \\
\text { deviation }\end{array}$ \\
\hline $\begin{array}{l}\text { This advertisement is very appealing to me. } \\
\text { (R) I probably would not pay attention to this advertisement if I saw it in }\end{array}$ & V49 & 2.89 & 1.148 \\
a magazine. & V50 & 2.87 & 1.128 \\
This is a warm advertisement and it moves me emotionally. & V51 & 3.04 & 1.152 \\
(R) This advertisement is of little interest for me. & V52 & 2.70 & 1.075 \\
(R) I do not like this advertisement. & V53 & 2.73 & 0.967 \\
This advertisement makes me feel good. & V54 & 2.59 & 1.009 \\
This is a wonderful advertisement. & V55 & 3.06 & 1.093 \\
(R) This is an advertisement that you forget easily. & V56 & 2.63 & 0.977 \\
This is a fascinating advertisement. & V57 & 2.96 & 1.013 \\
(R) I am tired of this style of advertisement. & V58 & 2.22 & 0.937 \\
(R) This advertisement makes me shiver. & V59 & 3.87 & 0.808 \\
This advertisement is easy to understand. & V60 & 3.56 & 0.908 \\
This advertisement is up to date. & V61 & 2.65 & 0.951 \\
This advertisement is honest. & V62 & 2.63 & 1.047 \\
\hline This advertisement is worth remembering. & &
\end{tabular}

Source: Authors' calculations based on survey data

Note: $(\mathrm{R})$ reverse coding 
Table 8 - Observable Variables and Analysis of Brand Evaluation

\begin{tabular}{|c|c|c|c|c|}
\hline & Observable variable & Name & Mean & $\begin{array}{l}\text { Standard } \\
\text { deviation }\end{array}$ \\
\hline \multirow{7}{*}{ 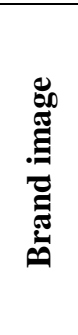 } & It conveys youth. & V63 & 3.90 & 0.994 \\
\hline & It conveys emotion. & V64 & 3.54 & 1.062 \\
\hline & It conveys fun. & V65 & 3.84 & 0.974 \\
\hline & It conveys energy. & V66 & 3.67 & 1.040 \\
\hline & It conveys freedom. & V67 & 3.58 & 1.074 \\
\hline & It conveys pleasure. & V68 & 3.89 & 0.998 \\
\hline & It conveys modernity. & V69 & 3.67 & 1.057 \\
\hline \multirow{4}{*}{ 至 } & I recommend Coca-Cola to my friends and relatives. & V70 & 2.70 & 1.334 \\
\hline & I speak positively about Coca-Cola to others. & V71 & 2.63 & $1 . .268$ \\
\hline & I intend to continue talking positively about the brand to others. & V72 & 2.60 & 1.247 \\
\hline & I intend to continue consuming Coca-Cola. & V73 & 3.10 & 1.385 \\
\hline \multirow{3}{*}{ ن } & It conveys power. & V74 & 4.02 & 1.034 \\
\hline & It conveys credibility. & V75 & 3.58 & 1.048 \\
\hline & It conveys arrogance. & V76 & 3.18 & 1.096 \\
\hline \multirow{3}{*}{ ن } & It conveys tradition. & V77 & 4.19 & 0.889 \\
\hline & It has quality. & V78 & 3.82 & 1.052 \\
\hline & It has been present in several generations. & V79 & 4.42 & 0.777 \\
\hline \multirow{3}{*}{ की } & It conveys the idea of capitalism. & V80 & 4.20 & 0.950 \\
\hline & It is a monopoly. & V81 & 3.63 & 1.198 \\
\hline & It is linked to the U.S.A. & V82 & 3.91 & 1.113 \\
\hline
\end{tabular}

Source: Authors' calculations based on survey data

Note: CFIn: Current and future intentions; BBS: Beliefs regarding the role of the brand in society; Co. image: company image; Brand Tradi: Brand Tradition. 


\section{APPENDIX 2}

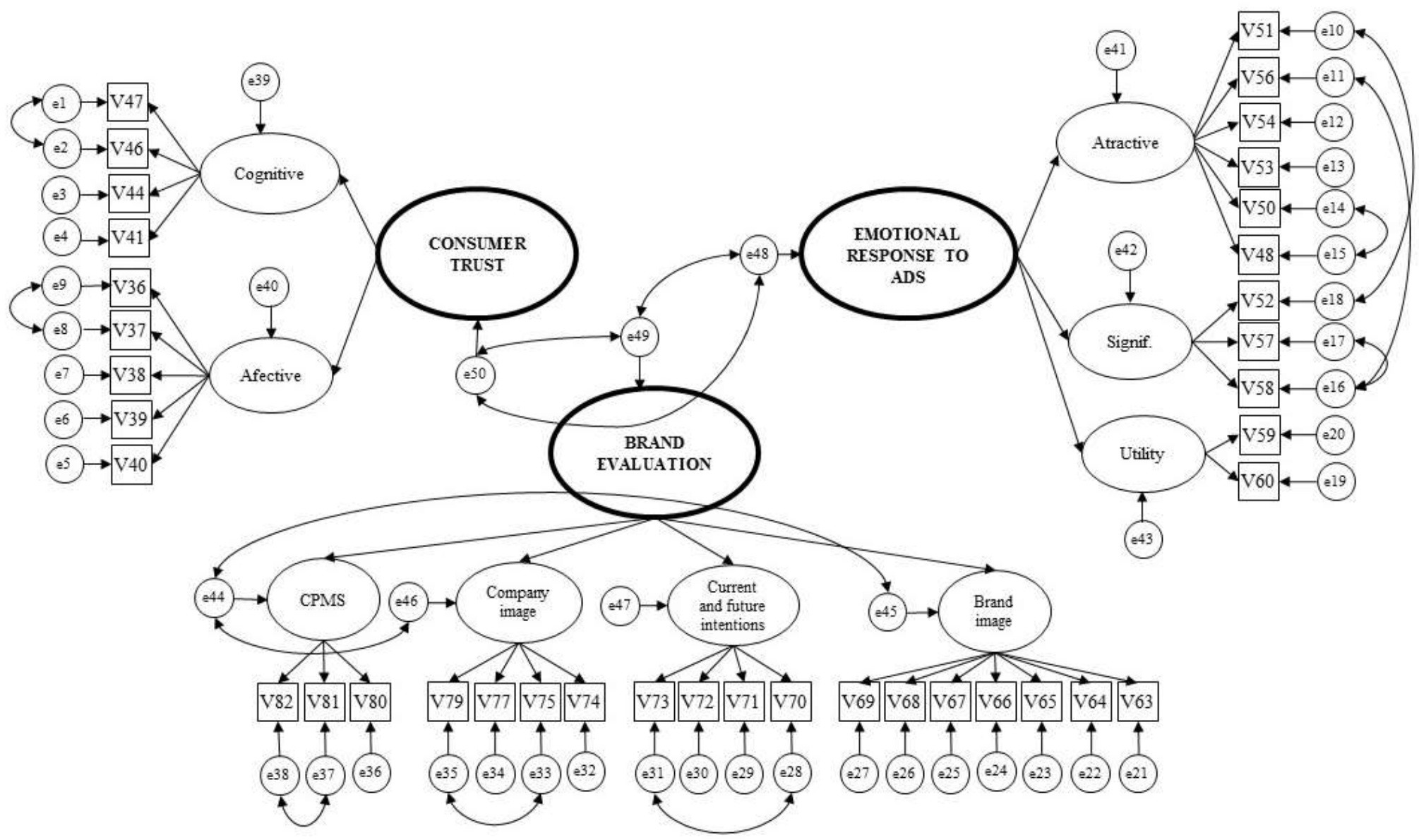

Figure 2 - Measure model

Note: The abbreviation refers to: CPMS - beliefs concerning the role of the brand in society; and ADS - advertising

Source: Authors' calculations based on survey data. 